Atmos. Chem. Phys., 13, 10919-10932, 2013

www.atmos-chem-phys.net/13/10919/2013/

doi:10.5194/acp-13-10919-2013

(c) Author(s) 2013. CC Attribution 3.0 License.

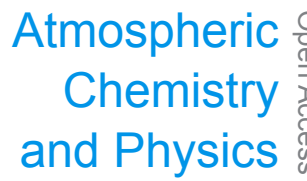

\title{
Characterization of organic aerosol produced during pulverized coal combustion in a drop tube furnace
}

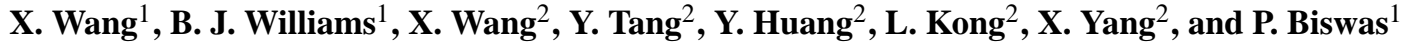 \\ ${ }^{1}$ Department of Energy, Environmental and Chemical Engineering, Washington University, St. Louis, USA \\ ${ }^{2}$ Department of Environmental Science and Engineering, Fudan University, Shanghai, China
}

Correspondence to: P. Biswas (pbiswas@wustl.edu) and X. Yang (yangxin@fudan.edu.cn)

Received: 19 October 2012 - Published in Atmos. Chem. Phys. Discuss.: 6 February 2013

Revised: 27 September 2013 - Accepted: 4 October 2013 - Published: 8 November 2013

\begin{abstract}
Controlled bench scale pulverized coal combustion studies were performed, demonstrating that inorganic particles play a critical role as carriers of organic species. Two commonly-used aerosol mass spectrometry techniques were applied to characterize fine particle formation during coal combustion. It was found that the organic species in coal combustion aerosols have mass spectra similar to those generated by biomass combustion. Ambient measurements in Shanghai, China confirm the presence of these species in approximately $29-38 \%$ of the sampled particles. With the absence of major biomass sources in the Shanghai area, it is suggested that coal combustion may be the main source of these particles. This work indicates there is a significant potential for incorrect apportionment of coal combustion particles to biomass burning sources using widely adopted mass spectrometry techniques.
\end{abstract}

\section{Introduction}

Pulverized coal combustion is used worldwide for the production of electricity with usage rates ranging from $45 \%$ in the United States to greater than $70 \%$ in India and China (Biswas et al., 2011). Coal combustion is a primary source of atmospheric aerosol (Seinfeld and Pandis, 2006), which adversely affects climate and human health (Poschl, 2005). While the characterization and fate of the mineral matter component of coal during combustion has been well studied and understood (Biswas and Wu, 1998; Linak and Wendt, 1994; Zhuang and Biswas, 2001), the characterization and fate of corresponding organic matter content has not yet been examined in detail. Although a few field stud- ies have suggested that primary particulate organic carbon emission from some power plants is very low (Zaveri et al., 2010; Peltier et al., 2007), power plants with lower combustion efficiency may still produce a significant amount of carbonaceous aerosol, including both black carbon and organic aerosol (OA), particularly in some developing countries where particle control technology is not extensively used. Some studies (Huggins et al., 2004; Shoji et al., 2002) reported that particulate matter, emitted from coal combustion, contains a significant fraction (up to $13-16 \%$ by mass) of carbonaceous matter. Recently, an ambient study reported that coal combustion sources contributed about $33 \%$ of total organic aerosol during the winter months in Beijing, China (Sun et al., 2013).

Particulate matter formation is closely associated with the burning of coal particles, which occurs in three steps as illustrated in Fig. S1 (Warnatz et al., 2006): (a) Pyrolysis of coal: Molecular structure of coal can be represented by clusters of many fused aromatic rings connected with other clusters via aliphatic bridges or loops. The aromatic bonds are very stable compared to the aliphatic bridges and loops. These bridges break up first during the heating of the coal particles. Some aromatic cluster fragments with lower molecular weights, referred to as "tar", are released into the gas phase due to their higher volatility. Meanwhile, larger molecularweight fragments remain in parent coal particles due to their lower volatility. The remaining particles are called "char"; (b) Burning of tar: Tar molecules that have been released to the gas phase are rapidly oxidized, and (c) Burning of char: Char is basically a mixture of carbon clusters and inorganic ash. The carbon on the char surface first reacts with $\mathrm{CO}_{2}$ and forms $\mathrm{CO}$. Then, the $\mathrm{CO}$ is oxidized in the gas phase. 
Organic matter may relate with soot particle formation from combustion. There are some studies which have investigated the formation mechanisms of soot particles from coal combustion. Brown and Fletcher (1998) proposed tar is the precursor to soot formation during coal combustion. Tar molecules have a relatively larger molecular weight, which allows them to form soot by directly losing $\mathrm{H}, \mathrm{O}$ and other atoms, without forming polycyclic aromatic hydrocarbons (PAHs). Rigby et al. (2000) found that soot yields decrease when flame temperature increases. And soot yields increase if the residence time of coal particles in the flame is increased, indicating that light-hydrocarbon may be incorporated into the soot while in the flame. Linak et al. (2007) reported carbon content in ultrafine particles (diameter $<500 \mathrm{~nm}$ ) is produced from coal combustion. They also found that carbon content could be correlated with toxicity of particles.

Only a few studies have characterized particulate organic emissions from pulverized coal combustion (Zhang et al., 2008; Linak et al., 2007). Zhang et al. (2008) measured emission factors of organic carbon (from 0.30 to $17.1 \mathrm{mg} \mathrm{kg}^{-1}$ of fuel depending on fuel types) for industrial coal boilers. They found $48-68 \%$ of particulate organic matter is organic acids. The main components also include polycyclic aromatic hydrocarbons (PAHs) and alkanes. Linak et al. (2007) combusted pulverized coal particles in a drop-tube furnace and reported that soot, which was considered to originate from tars, comprised a higher mass fraction of ultrafine particles (diameter $<500 \mathrm{~nm}$ ) than coarse particles, according to their $\mathrm{X}$-ray absorption near edge structure (XANES) spectra.

In developing countries, domestic coal combustion is used for household heating and cooking. Due to insufficient mixing of coal and air, much higher emissions of organic carbon have been found for domestic coal combustion (Oros and Simoneit, 2000; Tian et al., 2008). Oros and Simoneit (2000) used a gas chromatography-mass spectrometry (GCMS) to identify many organic compounds, including hydrocarbons, esters, ketones and other polar organic compounds. Tian et al. (2008) reported emission factors of hydrocarbon from coal combustion in a stove of 15.5 and $37.0 \mathrm{~g} \mathrm{~kg}^{-1}$ (of fuel) for anthracite coals and bituminous coals, respectively. Zhang el al. (2008) also measured the emission factors of organic carbon for domestic coal combustion, and reported the values to be 0.47 to $2.95 \mathrm{~g} \mathrm{~kg}^{-1}$ (of fuel) depending on coal types used.

In the past two decades, many advanced aerosol mass spectrometry techniques, such as thermal vaporization aerosol mass spectrometry and laser ablation single particle mass spectrometry, have been developed and widely used to characterize atmospheric aerosols and help identify their sources (Gard et al., 1997; Jimenez et al., 2003). Mass spectrum measured directly from source is crucial to source apportionment of aerosols using these aerosol mass spectrometry methods. Several studies have determined the mass spectra of aerosols produced from many sources such as biomass- burning stoves, diesel-burning vehicles, and cook stoves (Silva et al., 1999; Silva and Prather, 1997; Schneider et al., 2006; Mohr et al., 2009; Canagaratna et al., 2004). However, according to our knowledge, there are very few studies on organic aerosol characterization from coal combustion. For example, Healy et al. (2010) burned coal in an outdoor stove and measured its aerosol emission using a laser ablation single particle mass spectrometer. The obtained mass spectra were compared with ambient aerosol data; and a type of aerosol with similar mass spectra was identified from coal combustion. Similarly, Dall'Osto et al. (2013) obtained mass spectra of organic aerosols from a domestic peat and coal combustion experiment using a thermal vaporization aerosol mass spectrometer. They reported the mass spectra were similar to a type of organic aerosol; and concluded this type of organic aerosol originated from peat and coal combustion. Notably, all these studies focused on domestic coal combustion. Studies of organic aerosol emissions from pulverized coal combustion have not been conducted in detail using aerosol mass spectrometry techniques. This paper is an attempt to fill that information gap.

In this study, pulverized coal particles were combusted in a drop-tube furnace that was coupled with various aerosol instruments. A drop-tube furnace, a system commonly used to investigate pulverized coal combustion in the laboratory (Card and Jones, 1995; Cloke et al., 2002; Visona and Stanmore, 1999) due to its well-controlled temperature profile, gas composition and residence time, was used. Various mass spectrometry techniques such as thermal vaporization aerosol mass spectrometry and laser ablation single particle mass spectrometry were used to characterize and unravel the mechanistic details of the organic species' pathway during aerosol formation in coal combustors. These results were then used to identify the ambient aerosol in Shanghai from coal combustion sources.

\section{Experimental}

\subsection{Experimental setup and test plan of bench-scale pulverized coal combustion}

As shown in Fig. 1, the experimental setup consists of a droptube furnace (Lindberg/Blue M, Model HTF55342C, ThermoElectron Corp., USA) with an alumina tube $\left(5.72 \mathrm{~g} \mathrm{~kg}^{-1}\right.$ inner diameter and $121.92 \mathrm{~g} \mathrm{~kg}^{-1}$ long), a scanning mobility particle sizer (SMPS, TSI Inc., Shoreview, MN, USA), a high-resolution time-of-flight aerosol mass spectrometer (HR-Tof-AMS, Aerodyne Research Inc, MA, USA) and other supporting instruments. Pulverized Powder River Basin (PRB) sub-bituminous coal (coal particle diameter $<50 \mu \mathrm{m}$ ) was fed using a coal feeder (design of the feeder has been published elsewhere (Quann et al., 1982)) into the drop-tube furnace at feed rates ranging from 1 to $3.5 \mathrm{~g} \mathrm{~h}^{-1}$. Total 3 liter/min (LPM) carrier gas (air or additional- $\mathrm{N}_{2} /$ air mixture) 
Table 1. Summary of experimental conditions for drop-tube furnace study of pulverized coal combustion.

\begin{tabular}{|c|c|c|c|c|c|c|c|c|}
\hline Set & \# & $\begin{array}{l}\mathrm{O}_{2} / \text { Coal } \\
\text { Ratio } \\
\left(\mathrm{mol} \mathrm{mol}^{-1}\right)\end{array}$ & $\begin{array}{l}\text { Coal Feed } \\
\text { Rate } \\
\left(\mathrm{g} \mathrm{h}^{-1}\right)\end{array}$ & $\begin{array}{l}\text { Air Flow } \\
\text { Rate } \\
\text { (lpm) }\end{array}$ & $\begin{array}{l}\text { Additional } \\
\mathrm{N}_{2} \text { Flow } \\
\text { Rate } \\
(\mathrm{lpm})\end{array}$ & $\begin{array}{l}\text { Air/ } \\
\text { Additional- } \\
\mathrm{N}_{2} \text { Ratio }\end{array}$ & $\begin{array}{l}\text { Sampling } \\
\text { Dilution Ratio }\end{array}$ & Objective \\
\hline & 1 & 30.1 & 1 & 3 & 0 & - & & \\
\hline I & $\begin{array}{l}2 \\
3 \\
4 \\
5 \\
6\end{array}$ & $\begin{array}{l}20.1 \\
15.0 \\
12.0 \\
10.0 \\
8.6\end{array}$ & $\begin{array}{l}1.5 \\
2 \\
2.5 \\
3 \\
3.5\end{array}$ & $\begin{array}{l}3 \\
3 \\
3 \\
3 \\
3\end{array}$ & $\begin{array}{l}0 \\
0 \\
0 \\
0 \\
0\end{array}$ & $\begin{array}{l}- \\
- \\
- \\
- \\
-\end{array}$ & 100.7 & $\begin{array}{l}\text { Organic aerosol formation } \\
\text { under different } \mathrm{O}_{2} / \text { Coal ratios }\end{array}$ \\
\hline II & $\begin{array}{l}2 \\
3\end{array}$ & $\begin{array}{l}24.1 \\
18.1\end{array}$ & $\begin{array}{l}1 \\
1\end{array}$ & $\begin{array}{l}2.4 \\
1.8\end{array}$ & $\begin{array}{l}0.6 \\
1.2\end{array}$ & $\begin{array}{l}90 / 10 \\
80 / 20 \\
60 / 40\end{array}$ & 50.4 & $\begin{array}{l}\text { Organic aerosol formation under } \\
\text { different gas compositions at } \\
\text { lower coal feed rate }\left(\mathrm{g} \mathrm{h}^{-1}\right)\end{array}$ \\
\hline III & $\begin{array}{l}5 \\
6\end{array}$ & $\begin{array}{l}8.0 \\
6.0\end{array}$ & $\begin{array}{l}3 \\
3\end{array}$ & $\begin{array}{l}2.4 \\
1.8\end{array}$ & $\begin{array}{l}0.6 \\
1.2\end{array}$ & $90 / 10$ & 100.7 & $\begin{array}{l}\text { Organic aerosol formation under } \\
\text { different gas compositions at } \\
\text { higher coal feed rate }\left(3 \mathrm{~g} \mathrm{~h}^{-1}\right)\end{array}$ \\
\hline
\end{tabular}

was fed at the inlet to the furnace and passed through the alumina tube with coal particles. 1 LPM carrier gas was used in the coal feeder and carried coal particles into the furnace. Another 2 LPM carrier gas was introduced into the furnace directly. In this study, the wall temperature of the alumina tube was set at $1373 \mathrm{~K}$. Coal particles can be combusted completely when they travel through the alumina tube. At the exit of the combustor, 5 LPM particle-free air was added as primary dilution. The diluted exhaust gas passed through a six-stage cascade impactor (Mark III, Pollution Control System Corp., Seattle, WA) to remove particles with a diameter larger than $500 \mathrm{~nm}$. A slip stream with low flow rate was mixed with a high flow rate (details shown in Table 1) of particle-free air to achieve a secondary dilution after the impactor. A SMPS was used to obtain the particle size distribution in the range $9-425 \mathrm{~nm}$ (at least 4 SMPS scans were conducted for each experimental condition). Particulate organic matter was characterized by a thermal vaporization aerosol mass spectrometer (AMS, Aerodyne Research Inc.). Fine particles were also collected by quartz filters for further analysis. All experimental conditions are summarized in Table 1. Coal feed rates and gas compositions were changed in order to investigate formation mechanisms of OA during coal combustion.

\subsection{High-resolution time-of-flight aerosol mass spectrometer (HR-Tof-AMS)}

The Aerodyne quadrupole Aerosol Mass Spectrometer (QAMS) was described in detail by (Canagaratna et al., 2007; Allan et al., 2003; Jimenez et al., 2003). HR-Tof-AMS is a

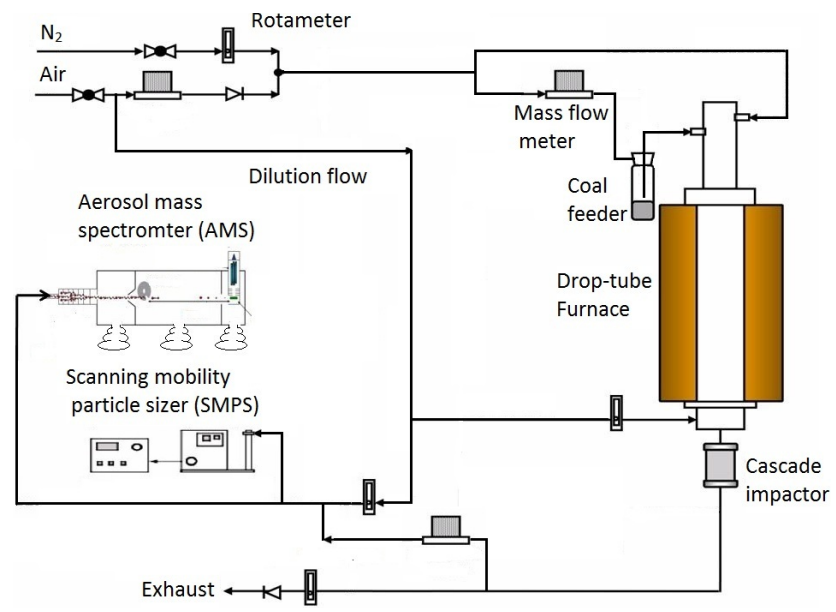

Fig. 1. Schematic drawing of the laboratory-scale pulverized coal combustion system with measurement instruments identified.

newer version of AMS and has better mass-to-charge ratio $(\mathrm{m} / \mathrm{z})$ resolution and faster response than the Q-AMS. The HR-Tof-AMS has been described in detail by DeCarlo et al. (2006). Briefly, aerosol particles are introduced into the AMS via the aerodynamic lens, which focuses the particles into a narrow beam. Particle size is resolved based on particle velocity across a time of flight chamber at the exit of the aerodynamic lens. Next, particles are impacted on a vaporizer where the non-refractory fraction is vaporized and immediately ionized using electron impact ionization. Finally, these ions are analyzed by a time-of-flight mass spectrometer. The vaporizer temperature was set to $600^{\circ} \mathrm{C}$. Coal combustion 
produces $\mathrm{CO}_{2}$, which will also contribute to some organic peaks like $m / z 28$ and 44 . A set of control experiments were conducted to determine and subtract the contribution of organic signal from background $\mathrm{CO}_{2}$. For each experimental condition, the AMS was running under the V-mode and the sampling time was about $15 \mathrm{~min}$. And filtered, particle-free exhaust gas measured by AMS was used as the baseline. By using high-resolution mass spectra, the exact molecular formula of each organic peak (e.g. $\mathrm{C}_{\mathrm{x}} \mathrm{H}_{\mathrm{y}} \mathrm{O}_{\mathrm{z}}$ ) was obtained, and overall elemental ratios for the entire mass spectrum was calculated. The method of elemental ratio calculation has been described by Aiken et al. (2007).

\subsection{Aerosol time-of-flight mass spectrometer (ATOFMS)}

The design and operation of ATOFMS (Model 3800, TSI Inc. Minnesota, USA) have been described by (Gard et al., 1997). Aerosols (with the diameter in the range from 0.1 to $3 \mathrm{mum}$ ) were introduced into the ATOFMS by vacuum through an aerodynamic lens that can focus and form a particle beam. Each particle has a size-dependent velocity, which is determined by the time-of-flight between two orthogonal, continuous diode-pumped lasers. The firing of the desorption/ionization laser (Nd:YAG laser, $266 \mathrm{~nm}$ ) is triggered when the particle enters the center region of the mass spectrometer. In this study, both positive and negative ions generated from laser ablation were analyzed simultaneously. The power density of $266 \mathrm{~nm}$ laser was maintained at approximately $1.0 \times 10^{8} \mathrm{~W} \mathrm{~cm}^{-2}$.

\subsection{Analysis of filter samples using total organic carbon (TOC) analyzer, aerosol time-of-flight mass spectrometer (ATOFMS) and gas chromatography- mass spectrometer (GC-MS)}

Particles (with diameters $<500 \mathrm{~nm}$ ) generated from the droptube furnace were collected on quartz filters and then analyzed with a total organic carbon analyzer (TOC-LCPH, Shimadzu Co.) for their total carbon content. These particles were then examined with a thermal/optical carbon analyzer (Model 2001, Atmoslytic Inc., Calabasas, CA) for the ratio of elemental carbon/organic carbon.

Particles collected on a quartz filter were also extracted by pure water in an ultrasonic bath. The extract was atomized to produce droplets. A diffusion dryer was used to dry the droplets. The dried aerosol was introduced into the ATOFMS and the mass spectra were obtained. Particles on a quartz filter were also extracted with $30 \mathrm{ml}$ mixture of dichloromethane and methanol ( $3: 1$ in volume). Then the extract was filtered and concentrated to about $5 \mathrm{ml}$ in a vacuum evaporator. A stream of ultrapure nitrogen was used to further concentrate the extract. Finally the extract was derivatized with BSTFA (BSTFA/TMCS, 99:1, Sigma-Aldrich
Co.) and introduced into a GC-MS (Thermo ISQ GC-MS, Thermo Fisher Scientific Inc.) for analysis.

\subsection{Ambient aerosol measurement in Shanghai}

Ambient aerosol measurements were conducted in the laboratory building of the Department of Environmental Science and Engineering at Fudan University $\left(31^{\circ} 17^{\prime} 47.14^{\prime \prime} \mathrm{N}\right.$, $\left.121^{\circ} 3^{\prime} 14.94^{\prime \prime} \mathrm{E}\right)$ in Shanghai during two periods (22-28 December 2009 and 17-22 March 2010). This site is within an urban residential area that is impacted by traffic, construction emissions and other urban area sources. Ambient air was drawn from a height of approximately $5.5 \mathrm{~m}$ above the ground and about $0.5 \mathrm{~m}$ above the roof of the building through a stainless steel tube, which was one-half inch diameter and $6 \mathrm{~m}$ long at a flow rate of $6 \mathrm{LPM}$. A slip stream of air was analyzed by an ATOFMS, which was running $24 \mathrm{~h}$ a day, just except some time for maintenance. The ATOFMS data was imported to YAADA (version 2.0, http://www.yaada. org, Copyright Jonathan O. Allen 2008), using a software toolkit for single particle data analysis written in MATLAB programming language (MATLAB, version 7.0). An adaptive resonance theory-based clustering method (ART-2a) was used to classify mass spectra (Song et al., 1999). Particles with sufficiently similar mass spectral patterns were manually merged into one class. The parameters used for ART2a included a vigilance factor of 0.85 , learning rate of 0.05 and 20 iterations. The resulting particle clusters were then grouped by hand into 7 general particle types according to mass spectral patterns. The grouped particles accounted for $95 \%$ of all the particles with bipolar mass spectra. During the second sampling period (17-22 March 2010), a Monitor for Aerosols \& Gas in Ambient Air (MARGA, Model ADI 2080, Applikon Analytical B.V., the Netherlands) was used to determine ionic potassium concentrations in $\mathrm{PM}_{2.5}$ of the ambient air. The detailed description of the field sampling using MARGA can be found in the literature (Du et al., 2011).

\section{Results and discussion}

The overall study examined the understanding of the pathways of organic aerosol formation by performing systematic experiments in a drop tube combustor. Using this information, the contribution of coal combustion sources to the ambient aerosol loading in Shanghai was established.

\subsection{Characterization of organic aerosol from coal combustion in a drop-tube furnace}

The average AMS organic mass spectra of aerosol from the drop tube coal combustor under various oxygen/coal ratios are shown in Fig. 2. Many significant organic peaks (such as $m / z 43,44,55,57,60,69,73,91$ ) are observed, confirming that pulverized coal combustion produces organic aerosols, even at the high oxygen/coal ratios in this efficient 
combustion system. The oxygen/coal ratio is defined as "feed rate of $\mathrm{O}_{2}$ in moles per hour/feed rate of carbon in moles per hour" and it ranged from 8.6 to 30.1 (In a full scale coal-fired power plant, a typical oxygen/coal ratio is 1.2 ). In combustion science, the equivalence ratio is commonly used, which is defined as the ratio of the fuel-to-oxidizer ratio to the stoichiometric fuel-to-oxidizer ratio; here the equivalence ratios ranged from 0.12 to 0.033 . However, the fraction of organic matter to total fine particle mass is small. Inorganic compounds, such as $\mathrm{SiO}_{2}, \mathrm{CaO}$ and $\mathrm{Al}_{2} \mathrm{O}_{3}$, are dominant species in coal combustion aerosol (Linak and Wendt, 1994). Figure S2 shows particle size distributions from the coal combustor, which indicates that changing oxygen/coal ratio from 30.1 to 8.6 slightly increased particle concentrations.

High-resolution (HR) aerosol mass spectrum can provide more detailed information on molecular formula for each ion. Figure 2B shows the HR spectrum for coal combustion aerosols at the oxygen/coal ratio at 12.0. It shows that $\mathrm{C}_{\mathrm{x}} \mathrm{H}_{\mathrm{y}}^{+}$, $\mathrm{C}_{\mathrm{x}} \mathrm{H}_{\mathrm{y}} \mathrm{O}^{+}$and $\mathrm{C}_{\mathrm{x}} \mathrm{H}_{\mathrm{y}} \mathrm{O}_{\mathrm{z}}^{+}$are the main ion series, and sulfur or nitrogen containing organic species do not contribute a significant fraction to the total organics. Some unit mass peaks, such as $m / z 43,44,57,60$, and 73 are considered as tracers of hydrocarbon organic aerosol (HOA), oxygenated organic aerosol (OOA), or biomass burning organic aerosol (BBOA) (Canagaratna et al., 2007). Thus, it is important to examine their HR peak patterns. Figure $2 \mathrm{c}$ shows the patterns for those peaks. The unit mass peak at $\mathrm{m} / \mathrm{z} 43$ is actually consisted of two ions: $\mathrm{C}_{2} \mathrm{H}_{3} \mathrm{O}^{+}(\mathrm{m} / z$ 43.018391) and $\mathrm{C}_{3} \mathrm{H}_{7}^{+}\left(\mathrm{m} / z\right.$ 43.054779). The peak of $\mathrm{C}_{3} \mathrm{H}_{7}^{+}$is much higher than $\mathrm{C}_{2} \mathrm{H}_{3} \mathrm{O}^{+}$. The ratio of these two ions can be considered as an indicator of the extent of oxygenation (Mohr et al., 2009). A higher $\mathrm{C}_{3} \mathrm{H}_{7}^{+} / \mathrm{C}_{2} \mathrm{H}_{3} \mathrm{O}^{+}$ratio suggests lower extent of oxygenation. Figure $2 \mathrm{~b}$ also shows a pronounced peak at $m / z, 44$, which is an important indicator for OOA. Figure $2 \mathrm{c}$ shows the unit mass peak at $m / z$ 44 is solely consisted of the ion $\mathrm{CO}_{2}^{+}(\mathrm{m} / \mathrm{z}$ 43.989830). It is formed via the thermal decarboxylation of carboxylic acids (Aiken et al., 2007). The fraction of $\mathrm{m} / \mathrm{z}, 44$ to the total organic signal, $\mathrm{f} 44$, is $7.5 \%$. And $\mathrm{f} 43$ is $9.3 \%$. According to $\mathrm{Ng}$ et al. (2011), the combination of these two values suggests that the organic compounds in this mass spectrum are semi-volatile OOAs, which are highly oxygenated. Similar to $\mathrm{m} / \mathrm{z} 43$, the unit mass peak at $\mathrm{m} / \mathrm{z} 57$ is dominantly composed of the ion $\mathrm{C}_{4} \mathrm{H}_{9}^{+}(\mathrm{m} / z$ 57.070431); and the ion $\mathrm{C}_{3} \mathrm{H}_{5} \mathrm{O}^{+}(\mathrm{m} / \mathrm{z}$ 57.034039) does not contribute a significant fraction for $m / z 57 . \mathrm{C}_{3} \mathrm{H}_{5} \mathrm{O}^{+}$ion is also an indicator for oxygenated species. The discrepancy between what is observed for HR analysis of $m / z 43$ and 57 being dominated by hydrocarbon fractions compared to the observed $\mathrm{m} / \mathrm{z}, 43$ to 44 ratio may suggest that most of the oxygenated species in coal combustion aerosol are carboxylic acids. Other oxygenated organic species, such as alcohol, ketone and aldehyde may not contribute a large fraction of total organic matter. One HR-AMS study (Aiken et al., 2007) has shown that pure oleic acid aerosol also produced higher $\mathrm{C}_{3} \mathrm{H}_{7}^{+}$and
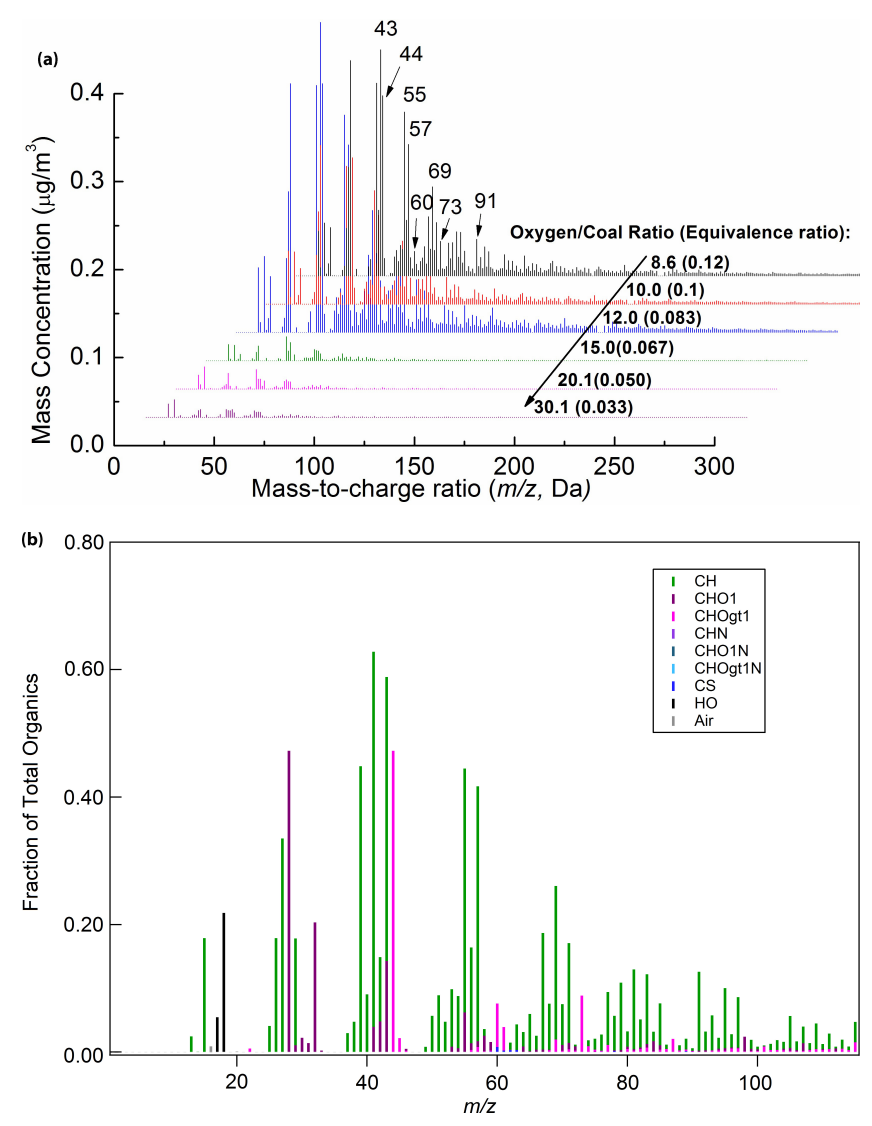

(c)
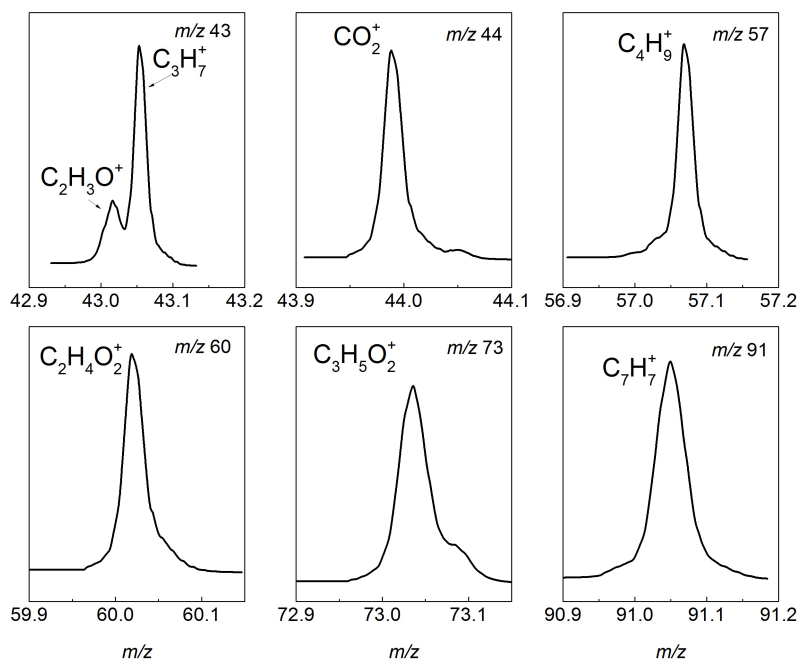

Fig. 2. (a) Average organic mass spectra for fine particulate matter from pulverized coal combustion under different oxygen/coal ratios. Each mass spectrum corresponds to one oxygen/coal ratio. The mass spectra were obtained by an Aerodyne Aerosol Mass Spectrometer (AMS); (b) High resolution AMS spectrum and (c) Some important high resolution peak patterns for fine particulate matter from pulverized coal combustion under the oxygen/coal ratio at 12.0. CHOgt1 represents a group of high resolution ions, including $\mathrm{CO}_{2}^{+2}, \mathrm{CO}_{2}^{+},{ }^{13} \mathrm{CO}_{2}^{+}, \mathrm{CH}_{2} \mathrm{O}_{2}^{+}, \mathrm{C}_{3} \mathrm{O}_{2}^{+}, \mathrm{C}_{8} \mathrm{H}_{5} \mathrm{O}_{3}^{+}, \mathrm{C}_{8} \mathrm{H}_{7} \mathrm{O}_{4}^{+}$, $\mathrm{C}_{16} \mathrm{H}_{23} \mathrm{O}_{4}^{+}$. 

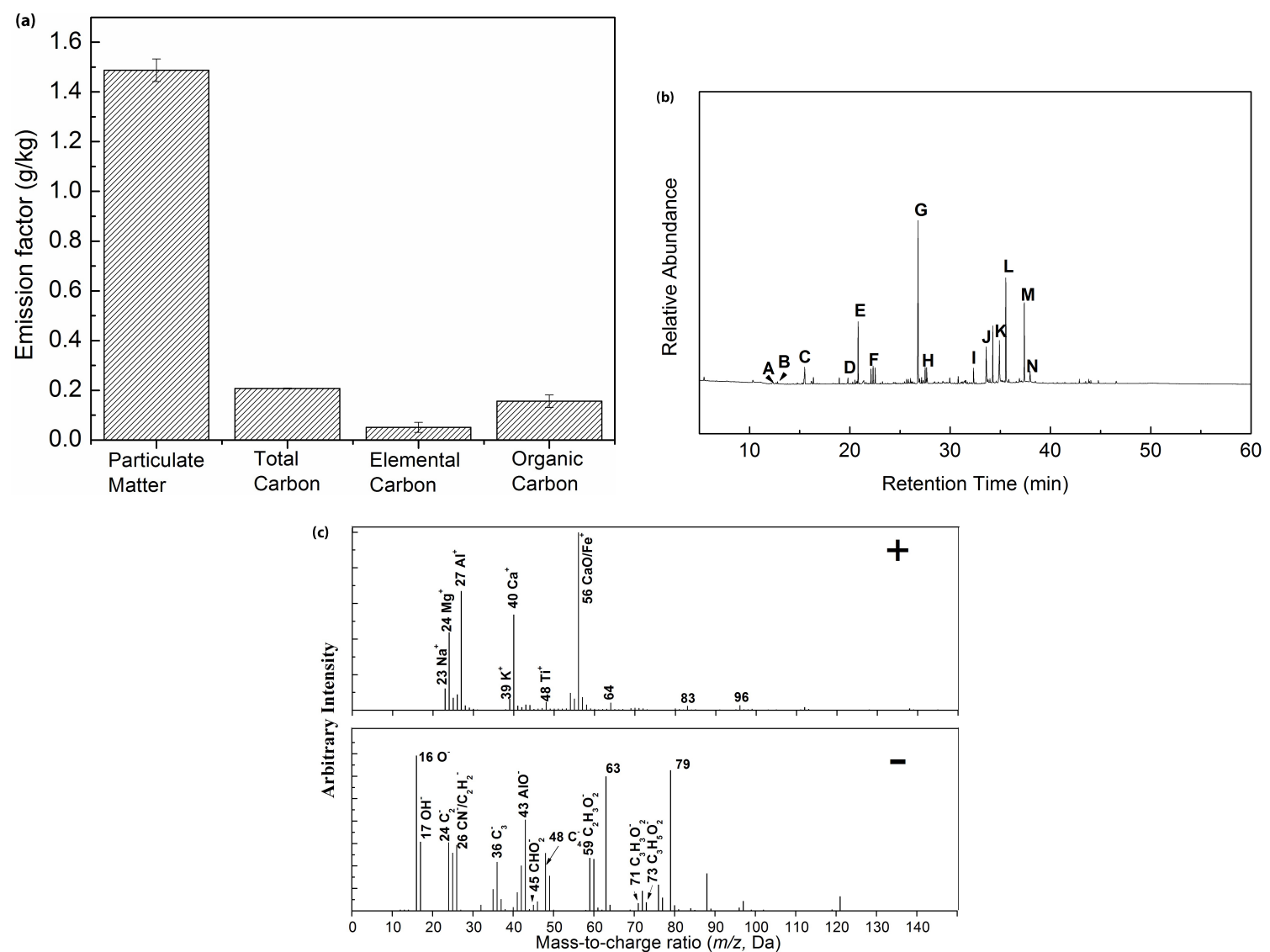

Fig. 3. (a) Emission factors of particulate matter, total carbon, elemental carbon and organic carbon from coal combustion. (b) GC-MS measurements of extracts from coal combustion particles. Different chemical compounds were separated depending on their retention time in GC column. Major compounds were identified according to their mass spectra: A. Benzaldehyde, 3-methoxy-4-[(trimethylsiyl)oxy],O-methyloxime; B. 3-Hydroxybutyric acid, t-butyl ester; C. Benzaldehyde, 2-methyl-; D. 1,3-Benzenediol,o-(4-methylbenzoyl)-o'(2methoxybenzoyl)-; E. Benzene, 1,3-bis(1,1-dimethylethyl)-; F. 2-Isopropyl-5-methyl-1-heptanol; G. Phenol,2,4-bis(1,1-dimethylethyl)-; H. Benzoic acid,3,5-bis(1,1-dimethylethyl)-4-hydroxy-,ethyl ester; I. 13-Docosen-1-ol,(Z)-; J. Hexadecanoic acid, methyl ester; K. nHexadecanoic acid; L. 14-Pentadecenoic acid; M. Oxtadecanoic acid, methyl ester; N. Oxtadecanoic acid. The presence of some esters may be due to the derivatization of acids with BSTFA; (c) Positive and negative mass spectra for extract of fine particulate matter from pulverized coal combustion. The mass spectra were obtained by an Aerosol Time-of-flight Mass Spectrometer (ATOFMS).

$\mathrm{C}_{4} \mathrm{H}_{9}^{+}$peaks but lower $\mathrm{C}_{2} \mathrm{H}_{3} \mathrm{O}^{+}$and $\mathrm{C}_{3} \mathrm{H}_{5} \mathrm{O}^{+}$peaks. In addition, the peak at $\mathrm{m} / \mathrm{z} 91$ should originate from aromatic compounds. The HR data (Fig. 2c) shows this peak mainly consists of the ion $\mathrm{C}_{7} \mathrm{H}_{7}^{+}(\mathrm{m} / z$ 91.054771), which contains a benzene ring.

The emission factors (EFs) of particulate matter, elemental carbon, and organic carbon were also determined (Fig. 3a). These values are higher than the EFs that a previous study reported (Bond et al., 2004), since real coal-fired power plants use electrostatic precipitator or fabric filter baghouse to remove fine particulate matter. EFs of particulate matter from coal combustion are highly dependent on particulate emission control devices. In developed areas like North America, particulate emission is strictly regulated. Thus, EFs of particulate matter from coal-fired power plants in these areas are very low. Some studies have shown that coal-fired power plants do not significantly contribute to primary organic aerosol emissions (Peltier et al., 2007; Zaveri et al., 2010). However, in developing areas with less pollutant control, EFs have very large uncertainties. The total carbon content in particulate matter in this case is about $13 \%$, which is in the range of the reported values for some industrial boilers (Zhang et al., 2008).

The mass spectra in Fig. 2a are similar to those from biomass burning aerosols that were reported by Schneider et al. (2006). Particularly, peaks at $m / z 60$ and 73 are generally considered as important biomass burning particle tracers. Figure 2c shows the HR peak pattern for $m / z 60$ and 73 . The main ion that contributes to $\mathrm{m} / z$, 60 is $\mathrm{C}_{2} \mathrm{H}_{4} \mathrm{O}_{2}^{+}$and is traditionally considered to result from fragmentation of levoglucosan, which is one of the major compounds emitted from biomass burning (Schneider et al., 2006; Weimer et al., 
2008). The fraction of $m / z 60$ to the total organic signal, f60, is $1.1 \%$ for Fig. 2B. Weimer et al. (2008) reports that f60 of wood combustion aerosol is from 0.6 to $6.7 \%$. Thus, this fraction is higher than the lower end of f60 for wood combustion aerosols. Therefore, coal combustion aerosol cannot be distinguished from wood combustion aerosol just based on $\mathrm{f} 60$. Similarly, $f 73$ for Fig. $2 \mathrm{~b}$ is $1.6 \%$, while $f 73$ for wood combustion aerosol is from 0.3 to $2.0 \%$ (Weimer et al., 2008). Figure $2 \mathrm{c}$ also shows that $\mathrm{C}_{3} \mathrm{H}_{5} \mathrm{O}_{2}^{+}$is the main ion for the peak at $\mathrm{m} / \mathrm{z}$ 73. To further characterize the organics, fine particulate matter from the coal combustor was collected on a quartz filter. The organics were extracted by a mixture of methanol and dichloromethane; derivatized with BSTFA and analysed by gas chromatography-mass spectrometry (GC/MS). No levoglucosan was detected (Fig. 3b), which implies that other detected compounds (e.g. some carboxylic acids) most likely contributed to the observed $\mathrm{m} / \mathrm{z} 60$ and 73. These masses have been previously observed with carboxylic acid samples in the AMS (Aiken et al., 2007). This observation implies that an ambient mass spectral signature with elevated $\mathrm{m} / \mathrm{z} 60$ and 73 could have biomass burning or coal combustion origins, and further supporting information is required to determine the major contributing source.

In the drop-tube coal combustion experiments, collected particles were also extracted with deionized water $(18 \mathrm{M} \Omega)$, then atomized and measured by an Aerosol Time-of-fight Mass Spectrometer (ATOFMS), which can analyse single aerosol particles by laser desorption/ionization (Gard et al., 1997). The ATOFMS mass spectrum (Fig. 3c) contains many inorganic peaks, such as $\mathrm{Ca}, \mathrm{Na}$ and $\mathrm{K}$. However, the $\mathrm{K}$ peak is comparatively low. This observation, however, is not consistent with the study by Suess et al. (2002) in which they observed larger $\mathrm{K}$ peaks in ATOFMS spectra for coal combustion particles in an in situ measurement (i.e. freshly emitted particles were directly introduced into ATOFMS and measured). The reason for the low K peak in this study is that $\mathrm{K}$ has high mineral affinity (elements associated with aluminosilicates, carbonates and other minerals in coal ash), and only about $1 \%$ of $\mathrm{K}$ in fly ash from coal combustion can be extracted by water (Querol et al., 1996). Peaks at $\mathrm{m} / \mathrm{z}$ of $-45,-59$ and -73 in ATOFMS spectra are usually considered as the fragments of levoglucosan (Silva et al., 1999). These peaks detected in Fig. $3 \mathrm{c}$ are not from levoglucosan in this study; hence they are not unique biomass burning tracers for particles in the atmosphere. The similarity of the organic species in aerosol formed during coal combustion and biomass burning is due to the fact that coal has its origins from biomass and was formed via coalification, which is a process that reduces hydrogen and oxygen content of biomass (with cellulose, lignin, hemicellulose being the major components) and increases the fraction of carbon content (Haenel, 1992).

\subsection{Formation mechanisms of organic aerosol from coal combustion}

OA formation is affected by oxygen/coal ratios. To examine this, the coal feed rate was changed while the air flow rate remained fixed. Figure 2 contrasts mass spectra between higher oxygen/coal ratios (15.0-30.1) and lower oxygen/coal ratios (8.6-12.0). When the oxygen/coal ratio is lower than 12.0, the peak of $\mathrm{CO}_{2}^{+}$at $\mathrm{m} / \mathrm{z} 44$ becomes one of the dominant peaks in the mass spectrum, suggesting that OOA is a major component of particulate organic matter. High-resolution AMS has the capability to determine elemental composition of organics (Aiken et al., 2008). At a lower oxygen/coal ratio, the $\mathrm{O} / \mathrm{C}$ molar ratios of the organic matter are around 0.25 (Fig. S3), which is similar to some fresh secondary organic aerosols generated in chamber experiments ( $\mathrm{Ng}$ et al., 2010). Larger char particles were removed by the impactor as they have particle diameters larger than $1 \mu \mathrm{m}$. Therefore, the oxygenated organic matter should be formed from tar, which is composed of volatile products of coal pyrolysis. GC/MS measurement shows that the composition of the organics is mainly comprised of oxidized aromatic compounds and some fatty acids (Fig. 3b), which could be the oxidized tar compounds. At higher oxygen/coal ratio (>15.0), abundance of the organic peaks is much lower, indicating OA formation is favored at lower oxygen/coal ratios.

Organic matter is typically fully oxidized (to gaseous $\mathrm{CO}_{2}$ and $\mathrm{CO}$ ) in air at high combustion temperatures. Thus, the organic matter detected in the particles was probably prevented from oxidation by unknown mechanisms in the combustor. A conjecture is proposed: the organic vapors are adsorbed by inorganic particles during coal combustion. After adsorption of organic vapors, inorganic particles may continue to grow, thereby covering and protecting organic matter from further oxidation. To test this hypothesis, different amounts of pure $\mathrm{N}_{2}$ were added into the coal combustor to suppress inorganic particle formation (a mechanism explained in our research group's previous study (Suriyawong et al., 2006)). Formation of OA particles should be favored under fuel-rich conditions, which would be the case when more $\mathrm{N}_{2}$ is added into the system as the oxygen/coal ratio is lowered. However, as shown in Fig. $4 \mathrm{a}$, when more $\mathrm{N}_{2}$ was added at a fixed coal feed rate of $3.0 \mathrm{~g} \mathrm{~h}^{-1}$, organic peaks became significantly lower compared to the air case (lower nitrogen concentrations). Both the total particle number concentration and size became smaller, resulting in lower inorganic ash particle concentrations (Suriyawong et al., 2006). At the reduced overall inorganic particle concentrations, the surface area available for adsorption of organic vapor was also reduced (Fig. 4b). The similar phenomenon (Fig. S4) was also observed for an experiment with a lower coal feed rate $\left(1.0 \mathrm{~g} \mathrm{~h}^{-1}\right)$.

It could be hypothesized that decreased oxygen content suppressed the oxidation of tar and thus suppressed formation of the OA mass; however, Fig. $4 \mathrm{c}$ shows that the O/C ratio of particulate organic matter actually increases when the 

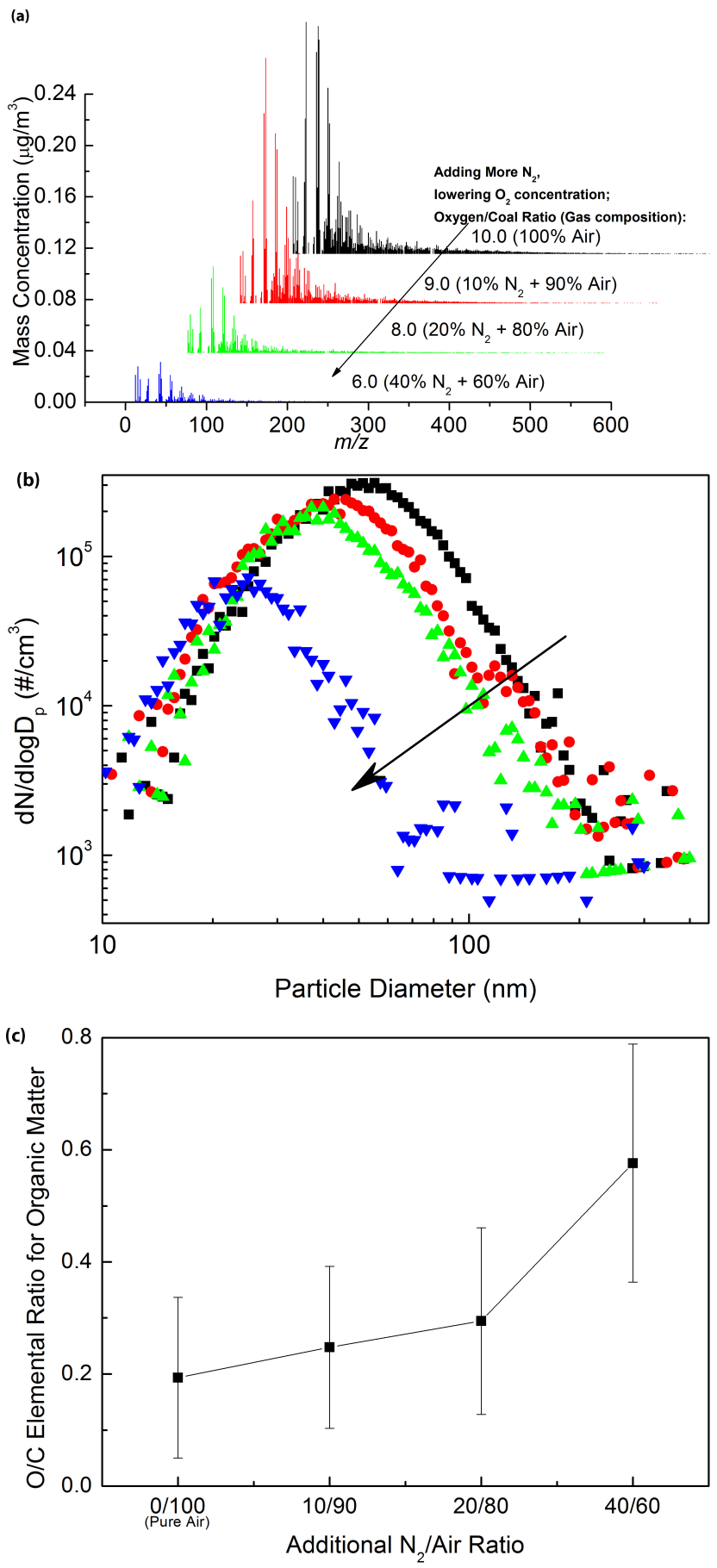

Fig. 4. (a) Average organic mass spectra and (b) Size distributions for different additional- $\mathrm{N}_{2}$ /Air ratios while coal feed rate was fixed at $3.0 \mathrm{~g} \mathrm{~h}^{-1}$. The mass spectra were obtained by AMS, while the size distributions were measured by SMPS. Each color of mass spectrum or size distribution corresponds to certain additional$\mathrm{N}_{2}$ /Air ratios: (Blank: Air; Red: $10 \% \mathrm{~N} 2+90 \%$ Air; Green: $20 \%$ $\mathrm{N} 2+80 \%$ Air; Blue: $40 \% \mathrm{~N} 2+60 \%$ Air); (c) Oxygen/Carbon $(\mathrm{O} / \mathrm{C})$ elemental ratios with error bars of organic matter for different additional- $\mathrm{N}_{2} /$ Air ratios.
$\mathrm{N}_{2}$ /Air ratio increases, providing further support for the proposed mechanism where inorganic aerosol is protecting OA mass from further oxidation. Notably, the error bars shown in Fig. $4 \mathrm{C}$ are large. A t-test was applied: The p-value between pure air (0/100) and $40 \% \mathrm{~N}_{2}$ addition (40/60) was less than 0.0001 , which is considered to be extremely statistically significant. The p-values between (0/100) and (10/90), (10/90) and (20/80), (20/80) and (40/60) were 0.27, 0.50 and 0.04, respectively. The Van Krevelen diagram was designed to show change of elemental compositions during coal evolution (Van Krevelen, 1950). This diagram has been used more recently for the evolution of organic aerosol in the atmosphere (Heald et al., 2010). Here, the Van Krevelen diagram of organic aerosols produced from coal combustion under the different $\mathrm{N}_{2}$ /Air ratios is shown in Fig. S5. The slope of the trend line is -0.24 , which is between 0 and -1 , suggesting that the oxidation process may produce more carboxylic acids and alcohol/peroxides (Heald et al., 2010). As previously mentioned, alcohol species may not contribute a significant fraction to coal combustion organic aerosol. Thus, the oxidation process may largely produce more carboxylic acids and organic peroxides. Thus, generally the trend is significant: $\mathrm{O} / \mathrm{C}$ ratio increased, when more $\mathrm{N}_{2}$ was added into the system. Under lower additional- $\mathrm{N}_{2} /$ Air ratio, higher concentrations of inorganic particles are formed during coal combustion. With increased surface area, they adsorb more organic species, and prevent their further oxidation. Thus, the $\mathrm{O} / \mathrm{C}$ ratio in the particulate matter is lower even under higher oxygen concentration (lower $\mathrm{N}_{2}$ /Air ratio), which is consistent with observations in Fig. 4c. In addition, size distributions of particles from coal combustion result in a maximum peak diameter of about $50 \mathrm{~nm}$ (Fig. S2). However, organic mass size distributions peak at about $100 \mathrm{~nm}$ (Fig. S6), indicating organic matter is associated with the larger particles that have a higher surface area and provide better protection against oxidation.

Figure 5 summarizes the proposed formation mechanisms of OA during pulverized coal combustion: Molecules in coal usually contain aromatic clusters which are connected by hydrocarbon bridges and loops (Haenel, 1992). The bond strength of aromatic rings is much greater than those of the hydrocarbon bridges and loops. When coal particles are combusted in the furnace, bridges and loops break apart first. Tar, a group of compounds with smaller molecular weights, are released. In the furnace, most of gas-phase tar is quickly oxidized and fully combusted. However, some of the tar species are adsorbed by the inorganic ash particles with chemical composition such as $\mathrm{SiO}_{2}, \mathrm{Al}_{2} \mathrm{O}_{3}, \mathrm{CaO}$ and sulfate. These particles can protect tar from further oxidation. Therefore, particulate organic matter survives the highly oxidizing environment and may potentially be emitted to the atmosphere. 


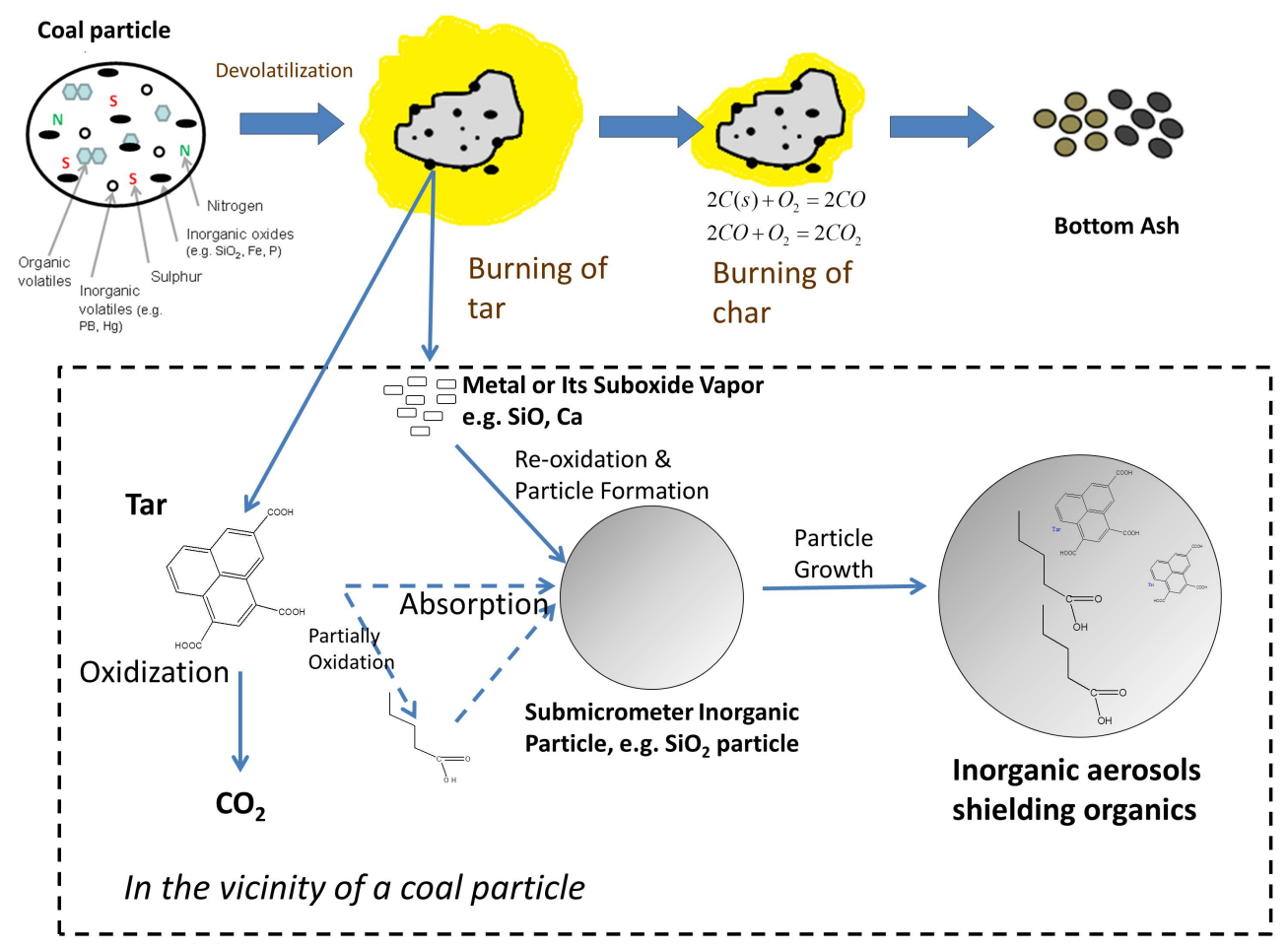

Fig. 5. Proposed formation mechanisms of OA from coal combustion.

\subsection{Identification of coal combustion aerosol in urban atmosphere}

Combustion is a major source category contributor to the atmospheric aerosol (Bond et al., 2004). According to this study, particles from coal combustion are a mixture of inorganic and organic compounds and mass spectral signatures overlap with some well-known biomass burning tracers. Particles emitted from coal combustors have the potential to be incorrectly assigned as biomass burning aerosol by tracerbased source apportionment. This was demonstrated for the ambient aerosol sampled in Shanghai, China.

Ambient aerosol was measured in Shanghai using ATOFMS for two different periods ( 22-28 December 2009, 17-22 March 2010). According to the similarity of the mass spectra, particles can be classified into several different types using ART-2a, a clustering algorithm (Song et al., 1999). As Fig. 6a shows, a unique type of particle is found, which accounts for about $29-38 \%$ of the total number of particles (Fig. 6b). It has dominant potassium $\left(\mathrm{K}^{+}, m / z\right.$ 39) peaks in the positive spectrum and secondary inorganic peaks $\left(\mathrm{NO}_{2}^{-}\right.$, $\mathrm{NO}_{3}^{-}, \mathrm{HSO}_{4}^{-}$, etc.) in the negative spectrum. $\mathrm{Li}, \mathrm{Al}, \mathrm{Ca}$, $\mathrm{CaO} / \mathrm{Fe}$ and other metal/metal oxide peaks were also present. In addition, there are some organic peaks and elemental carbon peaks. Notably, $\mathrm{CHO}_{2}^{-}(\mathrm{m} / z-45), \mathrm{C}_{2} \mathrm{H}_{3} \mathrm{O}_{2}^{-}(\mathrm{m} / z-59)$ and $\mathrm{C}_{3} \mathrm{H}_{5} \mathrm{O}_{2}^{-}(\mathrm{m} / \mathrm{z}-73)$ were found in the negative spectrum. Generally speaking, this mass spectral pattern is very similar to biomass burning aerosol that was identified in pre- vious ATOFMS field studies (Moffet et al., 2008; Hatch et al., 2011). Particularly, it contains $\mathrm{K}^{+}, \mathrm{CHO}_{2}^{-}, \mathrm{C}_{2} \mathrm{H}_{3} \mathrm{O}_{2}^{-}$and $\mathrm{C}_{3} \mathrm{H}_{5} \mathrm{O}_{2}^{-}$peaks, which are considered as tracers for biomass burning aerosol in previous studies (Silva et al., 1999; Moffet et al., 2008).

One significant biomass burning source in/around Shanghai is the open field burning of crop straw, which usually occurs from May to June every year (Du et al., 2011). Water-soluble potassium is a good tracer for biomass burning aerosols (Gaudichet et al., 1995). Du et al. (2011) confirmed the presence of very high water-soluble particulate potassium concentrations (the mass fraction was up to about $30 \%$ ) during the crop burning season (Fig. 7). However, in the study during 17-22 March 2010, the concentration of water-soluble $\mathrm{K}^{+}$in $\mathrm{PM}_{2.5}$ was much lower (shown in Fig. 7; the mass fraction was around 1-2\%); while the particle type from ATOFMS detection shown in Fig. 6a still accounts for over $38 \%$ of the total number of particles during this period. In addition, the land fire monitoring data from MODIS Rapid Response System (http://maps.geog.umd.edu) clearly shows that no open fire was detected in Shanghai and its surrounding areas (Fig. 8) during the sampling period of this study. Moreover, according to the China energy statistical yearbook (National Bureau of Statistics of China, 2008), biomass is not listed as a major energy source for industrial or households in Shanghai. Therefore, there are very few biomass burning sources during the sampling periods. Biomass burning aerosol was not the dominant aerosol type during this 


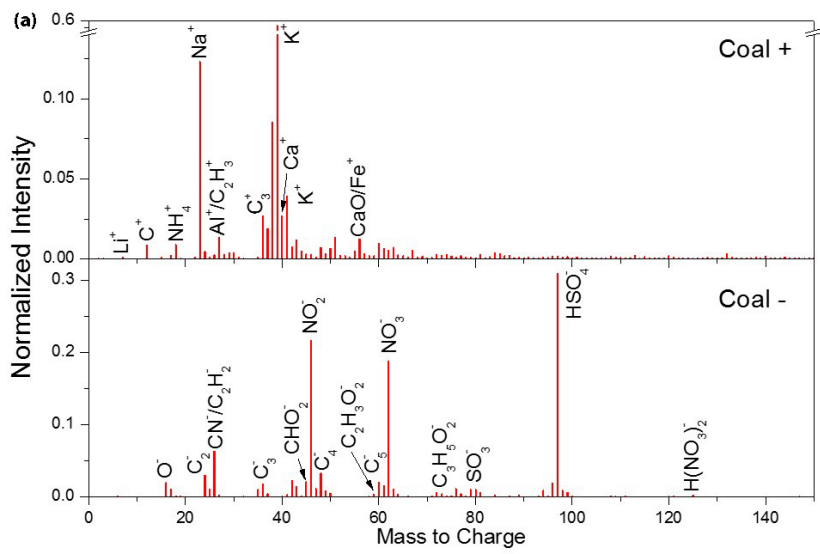

(b)

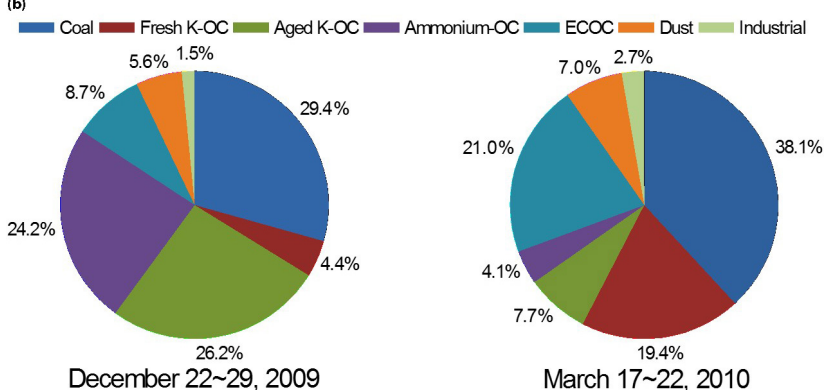

Fig. 6. (a) Average mass spectra of a dominant type of ambient aerosol in Shanghai using ATOFMS. The type of particles shown here are assigned as coal combustion particles. (b) Fraction of each particle type by number concentration during the sampling periods (22-28 December 2009 and 17-22 March 2010). The mass spectra of other particle types are shown in Fig. S7 in the Supplement. The particle type shown in (a) is assigned as "Coal", indicating that the particles in this category were most likely emitted from coal combustion.

period. This particle type should be representative of a different source.

The ATOFMS show that about $40 \%$ of particles contain very high potassium signals (Fig. 7). Since very low water-soluble potassium was observed, it strongly suggests that most of the potassium in the aerosol sampled in this study was not water-soluble. According to this study, $\mathrm{K}^{+}$, $\mathrm{CHO}_{2}^{-}, \mathrm{CH}_{3} \mathrm{O}_{2}^{-}$and $\mathrm{C}_{3} \mathrm{H}_{5} \mathrm{O}_{2}^{-}$peaks can also be present in the ATOFMS spectra of particles from coal combustion. This leads us to conclude that the dominant type of aerosols during this study was very likely produced from coal combustion. Coal provided about $66 \%$ of the total energy for Shanghai in 2008. Most coal is used for electricity generation and industry use (Fig. 9). Thus, it is possible that coal combustion generates a significant amount of particulate matter that is released to the atmosphere because of the relatively loose regulation of air pollutant emissions in China (Chen et al., 2006). Domestic coal burning may also play a significant role in aerosol emission due to its higher emission factors (Zhang et al., 2008). Moreover, the Shu et al. (2001) study also shows

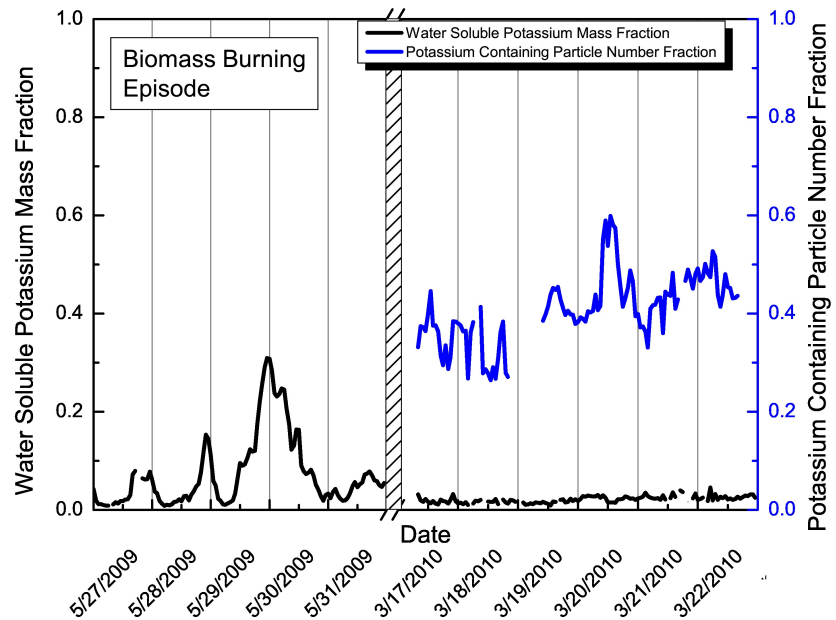

Fig. 7. Comparison of water-soluble potassium mass fraction and the number fraction of the aerosol type which is shown in Fig. 6a. The data for the biomass burning episode is adapted from $\mathrm{Du}$ et al. (2011).

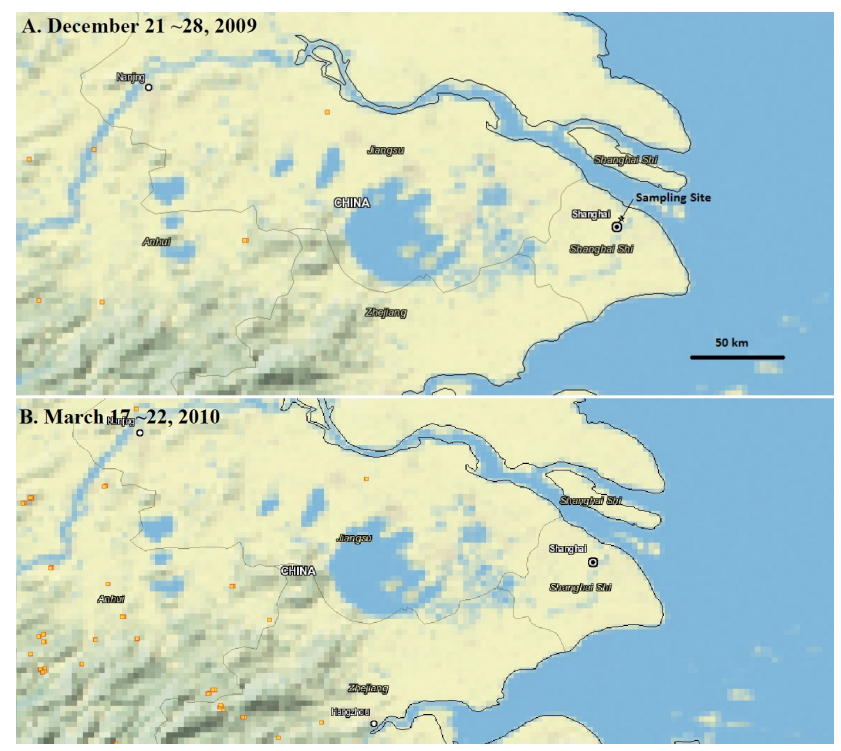

Fig. 8. Open fire event in/around Shanghai (Sampling site: $31^{\circ} 17^{\prime} 47.14^{\prime \prime} \mathrm{N}, 121^{\circ} 30^{\prime} 14.94^{\prime \prime} \mathrm{E}$ ) during sampling periods. Each orange square represents a single fire event.

that coal combustion contributes $19.6-60.1 \%$ of total suspended particle mass in Shanghai. Thus it is reasonable that this dominant aerosol type observed in the atmosphere was from coal combustion. Weaker peaks of $\mathrm{Al}^{+}, \mathrm{Ca}^{+}, \mathrm{CaO} / \mathrm{Fe}^{+}$ shown in Fig. 6a may be due to the aging process of aerosols in the atmosphere: Oxides of $\mathrm{Al}, \mathrm{Ca}$, and $\mathrm{Fe}$ can quickly react with $\mathrm{H}_{2} \mathrm{SO}_{4}$ in the atmosphere to form sulfates which have a much lower ionization efficiency in the ATOFMS (Middlebrook et al., 2003). Therefore, the $\mathrm{Al}^{+}, \mathrm{Ca}^{+}$, and $\mathrm{CaO} / \mathrm{Fe}^{+}$ peaks will be much weaker than those in freshly emitted particles. 


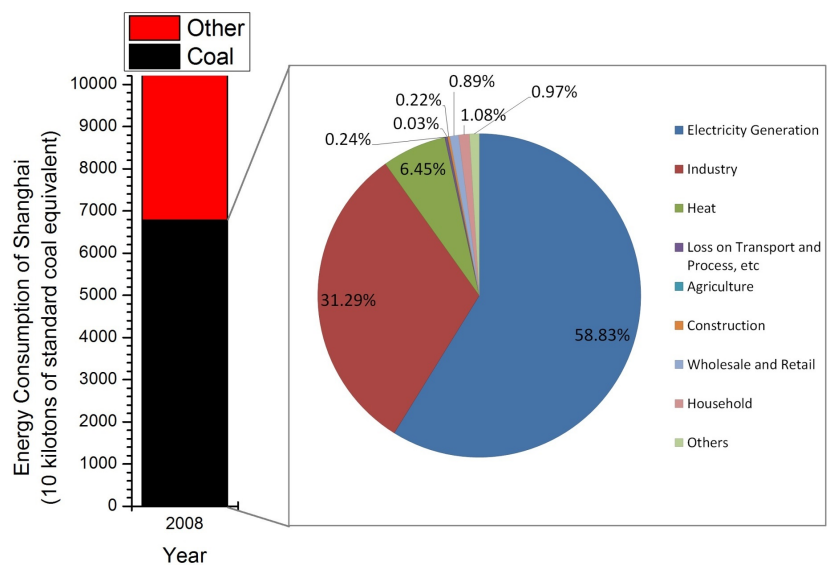

Fig. 9. Energy consumption in Shanghai during 2008. Coal combustion is the largest energy source. Breakdown by usage of coal is also shown. The data in this panel is adapted from referenced values (National Bureau of Statistics of China, 2008).

Other field studies have also reported certain types of ambient aerosols originating from coal combustion. For instance, a series of studies on ambient aerosol in Pittsburgh (Pekney et al., 2006; Bein et al., 2006; Bein et al., 2007) suggested that the particles with the signal of $\mathrm{Na} / \mathrm{Si} / \mathrm{K} / \mathrm{Ca} / \mathrm{Fe} / \mathrm{Ga} / \mathrm{Pb}$ were associated with coal combustion emissions. However, Healy et al. (2010) showed that Ga and Fe were not present in their coal combustion aerosols. In this study, $\mathrm{Na} / \mathrm{K} / \mathrm{Ca} / \mathrm{Fe}$ and $\mathrm{Pb}$ were observed in the type of ambient aerosols, which is considered to originate from coal combustion (Figs. 6a and S8), but no significant peak of silicates and $\mathrm{Ga}$ was present. In addition, Liu et al. (2003) reported that coal combustion aerosols contain the signal of $\mathrm{Li}$, while both Healy et al. (2010) and this study did not find this signal.

The observed inconsistencies in the chemical composition of coal combustion emission are likely due to several factors. First, coal is a complex mixture of many elements. Different coal types have very different compositions. Second, combustion conditions play a very important role in particulate matter formation. The detailed formation mechanisms are described in the literature (Damle et al., 1982; Haynes et al., 1982; Quann et al., 1982; Zhuang and Biswas, 2001; Suriyawong et al., 2006). Fine particle formation is very sensitive to combustion conditions, such as temperature and gas composition. For example, Suriyawong et al. (2006) found that formation rates of submicrometer silicate particles can vary by several orders of magnitude due to the change of the flame temperature. Therefore, the chemical composition of submicrometer particles can be very different when combustion condition is changed. Third, air pollution control devices (APCDs) can greatly affect emissions of particulate matter. Different selections of APCDs can result in very different characteristics of particulate emissions.

The characteristics of coal combustion aerosol can be very different due to the differences in coal types, combustion conditions and applications of APCDs. A single universal tracer for coal combustion aerosol may not exist. Therefore, in order to identify coal particles in the atmosphere, more information will be needed. For example, a recent field study in Beijing (Sun et al., 2013) found a type of organic aerosols whose AMS mass spectrum was very similar to coal combustion samples in our study. With an analysis of seasonal trend and diurnal pattern of this type of aerosols, the authors concluded that it was coal combustion aerosol. In this study, the organic and inorganic mass spectral signatures of coal combustion aerosol, along with the regional coal usage and satellite data, were used to identify a group of ambient aerosol which was very likely from coal combustion.

\section{Conclusions}

Coal combustion produces fine particles with a fraction of carbonaceous matter ( $\sim 13 \%$ of total mass in this study), including both black carbon and organic carbon. It is shown from controlled bench scale pulverized coal combustion studies that inorganic aerosols play a critical role as carrier of organic species. Using some commonly-used aerosol mass spectrometry techniques (Aerodyne AMS, GC-MS, and TSI ATOFMS), fine particulate matter from coal combustion was characterized in detail. The main OA components include oxidized aromatic matter and carboxylic acids. It was found that these organic species have similar mass spectra as those from biomass combustion aerosols. For atmospheric aerosol studies, due to the similarity of organic signals between coal combustion and biomass burning measured by both AMS and ATOFMS, some biomass burning aerosol tracers may not be reliable in certain locations.

These coal combustor emitted particles can be a major atmospheric aerosol source in some regions such as Shanghai where coal combustion accounts for a large fraction of electricity generation. Ambient measurements in Shanghai, China found the presence of some tracers, which were usually attributed to biomass burning, in about $29-38 \%$ of the sampled particles. With the absence of major biomass sources in the Shanghai area during the study period, it is suggested that coal combustion is probably the main source of these particles. This work shows that there is a significant potential for incorrect apportionment of coal combustion particles to biomass burning sources using widely adopted mass spectrometry techniques. The contribution of biomass burning aerosols may be overestimated if coal combustion systems are also present in the airshed. Therefore, it is critical to incorporate supporting information for the correct source apportionment of these particle types.

\footnotetext{
Supplementary material related to this article is available online at http://www.atmos-chem-phys.net/13/ 10919/2013/acp-13-10919-2013-supplement.pdf.
} 
Acknowledgements. This work was funded by the Consortium for Clean Coal Utilization at Washington University in St. Louis. Partial support by the National Natural Science Foundation of China (20937001) and the McDonnell Academy Global Energy and Environment Partnership (MAGEEP) are also acknowledged.

Edited by: C. K. Chan

\section{References}

Aiken, A. C., DeCarlo, P. F., and Jimenez, J. L.: Elemental analysis of organic species with electron ionization highresolution mass spectrometry, Anal. Chem., 79, 8350-8358, doi:10.1021/ac071150w, 2007.

Aiken, A. C., Decarlo, P. F., Kroll, J. H., Worsnop, D. R., Huffman, J. A., Docherty, K. S., Ulbrich, I. M., Mohr, C., Kimmel, J. R., Sueper, D., Sun, Y., Zhang, Q., Trimborn, A., Northway, M., Ziemann, P. J., Canagaratna, M. R., Onasch, T. B., Alfarra, M. R., Prevot, A. S. H., Dommen, J., Duplissy, J., Metzger, A., Baltensperger, U., and Jimenez, J. L.: O/C and OM/OC ratios of primary, secondary, and ambient organic aerosols with highresolution time-of-flight aerosol mass spectrometry, Environ. Sci. Technol., 42, 4478-4485, doi:10.1021/es703009q, 2008.

Allan, J. D., Jimenez, J. L., Williams, P. I., Alfarra, M. R., Bower, K. N., Jayne, J. T., Coe, H., and Worsnop, D. R.: Quantitative sampling using an Aerodyne aerosol mass spectrometer 1. Techniques of data interpretation and error analysis, J. Geophys. Res., 108, 4090, doi:10.1029/2002jd002358, 2003.

Bein, K. J., Zhao, Y., Pekney, N. J., Davidson, C. I., Johnston, M. V., and Wexler, A. S.: Identification of sources of atmospheric PM at the Pittsburgh Supersite - Part II: Quantitative comparisons of single particle, particle number, and particle mass measurements, Atmos. Environ., 40, S424-S444, doi:10.1016/j.atmosenv.2006.01.064, 2006.

Bein, K. J., Zhao, Y., Johnston, M. V., and Wexler, A. S.: Identification of sources of atmospheric PM at the Pittsburgh supersite - Part III: Source characterization, Atmos. Environ., 41, 39743992, doi:10.1016/j.atmosenv.2007.01.039, 2007.

Biswas, P. and $\mathrm{Wu}, \mathrm{C}$. Y.: Control of toxic metal emissions from combustors using sorbents: A review, J. Air Waste Manage. Assoc., 48, 113-127, 1998.

Biswas, P., Wang, W. N., and An, W. J.: The energy-environment nexus: aerosol science and technology enabling solutions, Front. Environ. Sci. Eng. China, 5, 299-312, doi:10.1007/s11783-0110351-1, 2011.

Bond, T. C., Streets, D. G., Yarber, K. F., Nelson, S. M., Woo, J.-H., and Klimont, Z.: A technology-based global inventory of black and organic carbon emissions from combustion, J. Geophys. Res., 109, D14203, doi:10.1029/2003jd003697, 2004.

Brown, A. L. and Fletcher, T. H.: Modeling Soot Derived from Pulverized Coal, Energy Fuels, 12, 745-757, doi:10.1021/ef9702207, 1998.

Canagaratna, M. R., Jayne, J. T., Ghertner, D. A., Herndon, S., Shi, Q., Jimenez, J. L., Silva, P. J., Williams, P., Lanni, T., Drewnick, F., Demerjian, K. L., Kolb, C. E., and Worsnop, D. R.: Chase Studies of Particulate Emissions from in-use New York City Vehicles, Aerosol Sci. Technol., 38, 555-573, doi:10.1080/02786820490465504, 2004.
Canagaratna, M. R., Jayne, J. T., Jimenez, J. L., Allan, J. D., Alfarra, M. R., Zhang, Q., Onasch, T. B., Drewnick, F., Coe, H., Middlebrook, A., Delia, A., Williams, L. R., Trimborn, A. M., Northway, M. J., DeCarlo, P. F., Kolb, C. E., Davidovits, P., and Worsnop, D. R.: Chemical and microphysical characterization of ambient aerosols with the aerodyne aerosol mass spectrometer, Mass Spectrom. Rev., 26, 185-222, doi:10.1002/mas.20115, 2007.

Card, J. B. A. and Jones, A. R.: A Drop Tube Furnace Study of Coal Combustion and Unburned Carbon Content Using Optical Techniques, Combust. Flame, 101, 539-547, doi:10.1016/00102180(94)00237-m, 1995.

Chen, C., Wang, B., Fu, Q., Green, C., and Streets, D. G.: Reductions in emissions of local air pollutants and co-benefits of Chinese energy policy: a Shanghai case study, Energy Pol., 34, 754762, doi:10.1016/j.enpol.2004.07.007, 2006.

Cloke, M., Lester, E., and Thompson, A. W.: Combustion characteristics of coals using a drop-tube furnace, Fuel, 81, 727-735, 2002.

Dall'Osto, M., Ovadnevaite, J., Ceburnis, D., Martin, D., Healy, R. M., O’Connor, I. P., Kourtchev, I., Sodeau, J. R., Wenger, J. C., and O'Dowd, C.: Characterization of urban aerosol in Cork city (Ireland) using aerosol mass spectrometry, Atmos. Chem. Phys., 13, 4997-5015, doi:10.5194/acp-13-4997-2013, 2013.

Damle, A. S., Ensor, D. S., and Ranade, M. B.: Coal Combustion Aerosol Formation Mechanisms - A Review, Aerosol Sci. Technol., 1, 119-133, 1982.

DeCarlo, P. F., Kimmel, J. R., Trimborn, A., Northway, M. J., Jayne, J. T., Aiken, A. C., Gonin, M., Fuhrer, K., Horvath, T., Docherty, K. S., Worsnop, D. R., and Jimenez, J. L.: Field-Deployable, High-Resolution, Time-of-Flight Aerosol Mass Spectrometer, Anal. Chem., 78, 8281-8289, doi:10.1021/ac061249n, 2006.

Du, H. H., Kong, L. D., Cheng, T. T., Chen, J. M., Du, J. F., Li, L., Xia, X. G., Leng, C. P., and Huang, G. H.: Insights into summertime haze pollution events over Shanghai based on online water-soluble ionic composition of aerosols, Atmos. Environ., 45, 5131-5137, doi:10.1016/j.atmosenv.2011.06.027, 2011.

Gard, E., Mayer, J. E., Morrical, B. D., Dienes, T., Fergenson, D. P., and Prather, K. A.: Real-time analysis of individual atmospheric aerosol particles: Design and performance of a portable ATOFMS, Anal. Chem., 69, 4083-4091, doi:10.1021/ac970540n, 1997.

Gaudichet, A., Echalar, F., Chatenet, B., Quisefit, J. P., Malingre, G., Cachier, H., Buat-Menard, P., Artaxo, P., and Maenhaut, W.: Trace elements in tropical African savanna biomass burning aerosols, J. Atmos. Chem., 22, 19-39, doi:10.1007/bf00708179, 1995.

Haenel, M. W.: Recent progress in coal structure research, Fuel, 71, 1211-1223, doi:10.1016/0016-2361(92)90046-q, 1992.

Hatch, L. E., Creamean, J. M., Ault, A. P., Surratt, J. D., Chan, M. N., Seinfeld, J. H., Edgerton, E. S., Su, Y., and Prather, K. A.: Measurements of Isoprene-Derived Organosulfates in Ambient Aerosols by Aerosol Time-of-Flight Mass Spectrometry - Part 1: Single Particle Atmospheric Observations in Atlanta, Environ. Sci. Technol., 45, 5105-5111, doi:10.1021/es103944a, 2011.

Haynes, B. S., Neville, M., Quann, R. J., and Sarofim, A. F.: Factors Governing the Surface Enrichment of Fly-ash in Volatile Trace Species, J. Colloid Interface Sci., 87, 266-278, 1982. 
Heald, C. L., Kroll, J. H., Jimenez, J. L., Docherty, K. S., DeCarlo, P. F., Aiken, A. C., Chen, Q., Martin, S. T., Farmer, D. K., and Artaxo, P.: A simplified description of the evolution of organic aerosol composition in the atmosphere, Geophy. Res. Lett., 37, L08803, doi:10.1029/2010GL042737, 2010.

Healy, R. M., Hellebust, S., Kourtchev, I., Allanic, A., O'Connor, I. P., Bell, J. M., Healy, D. A., Sodeau, J. R., and Wenger, J. C.: Source apportionment of PM2.5 in Cork Harbour, Ireland using a combination of single particle mass spectrometry and quantitative semi-continuous measurements, Atmos. Chem. Phys., 10, 9593-9613, doi:10.5194/acp-10-9593-2010, 2010.

Huggins, F. E., Huffman, G. P., Linak, W. P., and Miller, C. A.: Quantifying hazardous species in particulate matter derived from fossil-fuel combustion, Environ. Sci. Technol., 38, 1836-1842, doi:10.1021/es0348748, 2004.

Jimenez, J. L., Jayne, J. T., Shi, Q., Kolb, C. E., Worsnop, D. R., Yourshaw, I., Seinfeld, J. H., Flagan, R. C., Zhang, X., Smith, K. A., Morris, J. W., and Davidovits, P.: Ambient aerosol sampling using the Aerodyne Aerosol Mass Spectrometer, J. Geophys. Res., 108, 8425, doi:10.1029/2001jd001213, 2003.

Linak, W. P. and Wendt, J. O. L.: Trace metal transformation mechanisms during coal combustion, Fuel Process. Technol., 39, 173198, 1994.

Linak, W. P., Yoo, J.-I. K., Wasson, S. J., Zhu, W., Wendt, J. O. L., Huggins, F. E., Chen, Y., Shah, N., Huffman, G. P., and Gilmour, M. I.: Ultrafine ash aerosols from coal combustion: Characterization and health effects, Proc. Combust. Inst., 31, 1929-1937, doi:10.1016/j.proci.2006.08.086, 2007.

Liu, D.-Y., Wenzel, R. J., and Prather, K. A.: Aerosol time-offlight mass spectrometry during the Atlanta Supersite Experiment: 1. Measurements, J. Geophys. Res.-Atmos., 108, 8426, doi:10.1029/2001jd001562, 2003.

Middlebrook, A. M., Murphy, D. M., Lee, S. H., Thomson, D. S., Prather, K. A., Wenzel, R. J., Liu, D. Y., Phares, D. J., Rhoads, K. P., Wexler, A. S., Johnston, M. V., Jimenez, J. L., Jayne, J. T., Worsnop, D. R., Yourshaw, I., Seinfeld, J. H., and Flagan, R. C.: A comparison of particle mass spectrometers during the 1999 Atlanta Supersite Project, J. Geophys. Res., Atmos., 108, 8424, doi:10.1029/2001jd000660, 2003.

Moffet, R. C., de Foy, B., Molina, L. T., Molina, M. J., and Prather, K. A.: Measurement of ambient aerosols in northern Mexico City by single particle mass spectrometry, Atmos. Chem. Phys., 8, 4499-4516, doi:10.5194/acp-8-4499-2008, 2008.

Mohr, C., Huffman, J. A., Cubison, M. J., Aiken, A. C., Docherty, K. S., Kimmel, J. R., Ulbrich, I. M., Hannigan, M., and Jimenez, J. L.: Characterization of Primary Organic Aerosol Emissions from Meat Cooking, Trash Burning, and Motor Vehicles with High-Resolution Aerosol Mass Spectrometry and Comparison with Ambient and Chamber Observations, Environ. Sci. Technol., 43, 2443-2449, doi:10.1021/es8011518, 2009.

National Bureau of Statistics of China, N. E. A. o. C.: China energy statistical yearbook: 2008, National Bureau of Statistics of China; National Energy Administration of China, Beijing, 2008.

Ng, N. L., Canagaratna, M. R., Zhang, Q., Jimenez, J. L., Tian, J., Ulbrich, I. M., Kroll, J. H., Docherty, K. S., Chhabra, P. S., Bahreini, R., Murphy, S. M., Seinfeld, J. H., Hildebrandt, L., Donahue, N. M., DeCarlo, P. F., Lanz, V. A., Prevot, A. S. H., Dinar, E., Rudich, Y., and Worsnop, D. R.: Organic aerosol components observed in Northern Hemispheric datasets from
Aerosol Mass Spectrometry, Atmos. Chem. Phys., 10, 46254641, doi:10.5194/acp-10-4625-2010, 2010.

Ng, N. L., Canagaratna, M. R., Jimenez, J. L., Chhabra, P. S., Seinfeld, J. H., and Worsnop, D. R.: Changes in organic aerosol composition with aging inferred from aerosol mass spectra, Atmos. Chem. Phys., 11, 6465-6474, doi:10.5194/acp-11-64652011, 2011.

Oros, D. R. and Simoneit, B. R. T.: Identification and emission rates of molecular tracers in coal smoke particulate matter, Fuel, 79, 515-536, doi:10.1016/s0016-2361(99)00153-2, 2000.

Pekney, N. J., Davidson, C. I., Bein, K. J., Wexler, A. S., and Johnston, M. V.: Identification of sources of atmospheric PM at the Pittsburgh Supersite, Part I: Single particle analysis and filterbased positive matrix factorization, Atmos. Environ., 40, S411S423, doi:10.1016/j.atmosenv.2005.12.072, 2006.

Peltier, R. E., Sullivan, A. P., Weber, R. J., Wollny, A. G., Holloway, J. S., Brock, C. A., de Gouw, J. A., and Atlas, E. L.: No evidence for acid-catalyzed secondary organic aerosol formation in power plant plumes over metropolitan Atlanta, Georgia, Geophys. Res. Lett., 34, L06801, doi:10.1029/2006g1028780, 2007.

Pöschl, U.: Atmospheric aerosols: Composition, transformation, climate and health effects, Angew. Chem. Int. Ed., 44, 75207540, doi:10.1002/anie.200501122, 2005.

Quann, R. J., Neville, M., Janghorbani, M., Mims, C. A., and Sarofim, A. F.: Mineral Matter and Trace-element Vaporization in a Laboratory-pulverized Coal Combustion System, Environ. Sci. Technol., 16, 776-781, 1982.

Querol, X., Juan, R., Lopez-Soler, A., Fernandez-Turiel, J., and Ruiz, C. R.: Mobility of trace elements from coal and combustion wastes, Fuel, 75, 821-838, doi:10.1016/0016-2361(96)00027-0, 1996.

Rigby, J., Ma, J., Webb, B. W., and Fletcher, T. H.: Transformations of Coal-Derived Soot at Elevated Temperature, Energy Fuels, 15, 52-59, doi:10.1021/ef000111j, 2000.

Schneider, J., Weimer, S., Drewnick, F., Borrmann, S., Helas, G., Gwaze, P., Schmid, O., Andreae, M. O., and Kirchner, U.: Mass spectrometric analysis and aerodynamic properties of various types of combustion-related aerosol particles, Int. J. Mass Spectrom., 258, 37-49, doi:10.1016/j.ijms.2006.07.008, 2006.

Seinfeld, J. H. and Pandis, S. N.: Atmospheric Chemistry and Physics: From Air Pollution to Climate Change, 2, John Wiley \& Sons, Inc., Hoboken, NJ, USA, 370-384, 2006.

Shoji, T., Huggins, F. E., Huffman, G. P., Linak, W. P., and Miller, C. A.: XAFS spectroscopy analysis of selected elements in fine particulate matter derived from coal combustion, Energy Fuels, 16, 325-329, doi:10.1021/ef010200b, 2002.

Shu, J., Dearing, J. A., Morse, A. P., Yu, L., and Yuan, N.: Determining the sources of atmospheric particles in Shanghai, China, from magnetic and geochemical properties, Atmos. Environ., 35, 2615-2625, doi:10.1016/s1352-2310(00)00454-4, 2001.

Silva, P. J. and Prather, K. A.: On-line characterization of individual particles from automobile emissions, Environ. Sci. Technol., 31, 3074-3080, doi:10.1021/es961063d, 1997.

Silva, P. J., Liu, D.-Y., Noble, C. A., and Prather, K. A.: Size and Chemical Characterization of Individual Particles Resulting from Biomass Burning of Local Southern California Species, Environ. Sci. Technol., 33, 3068-3076, doi:10.1021/es980544p, 1999.

Song, X.-H., Hopke, P. K., Fergenson, D. P., and Prather, K. A.: Classification of Single Particles Analyzed by ATOFMS Using 
an Artificial Neural Network, ART-2A, Anal. Chem., 71, 860865, doi:10.1021/ac9809682, 1999.

Suess, D. T.: Single Particle Mass Spectrometry Combustion Source Characterization and Atmospheric Apportionment of Vehicular, Coal and Biofuel Exhaust Emissions, PhD, Chemistry, Univerisity of California, Riverside, CA, USA, 2002.

Sun, Y. L., Wang, Z. F., Fu, P. Q., Yang, T., Jiang, Q., Dong, H. B., Li, J., and Jia, J. J.: Aerosol composition, sources and processes during wintertime in Beijing, China, Atmos. Chem. Phys., 13, 4577-4592, doi:10.5194/acp-13-4577-2013, 2013.

Suriyawong, A., Gamble, M., Lee, M.-H., Axelbaum, R., and Biswas, P.: Submicrometer Particle Formation and Mercury Speciation Under O2-CO2 Coal Combustion, Energy Fuels, 20, 2357-2363, doi:10.1021/ef060178s, 2006.

Tian, L., Lucas, D., Fischer, S. L., Lee, S. C., Hammond, S. K., and Koshland, C. P.: Particle and Gas Emissions from a Simulated Coal-Burning Household Fire Pit, Environ. Sci. Technol., 42, 2503-2508, doi:10.1021/es0716610, 2008.

Van Krevelen, D. W.: Graphical-statistical method for the study of structure and reaction processes of coal, Fuel, 24, 269-284, 1950.

Visona, S. P., and Stanmore, B. R.: Modeling nitric oxide formation in a drop tube furnace burning pulverized coal, Combust. Flame, 118, 61-75, doi:10.1016/s0010-2180(98)00140-0, 1999.

Warnatz, J., Maas, U., and Dibble, R. W.: Combustion: Physical and Chemical Fudnamentals, Modeling and Simulation, Experiments, Pollutant Formation, 4 ed., Springer, Berlin, 255-258, 2006.
Weimer, S., Alfarra, M. R., Schreiber, D., Mohr, M., Prevot, A. S. $\mathrm{H}$., and Baltensperger, U.: Organic aerosol mass spectral signatures from wood-burning emissions: influence of burning conditions and wood type, J. Geophys. Res., -Atmos., 113, D10304, doi:10.1029/2007jd009309, 2008.

Zaveri, R. A., Berkowitz, C. M., Brechtel, F. J., Gilles, M. K., Hubbe, J. M., Jayne, J. T., Kleinman, L. I., Laskin, A., Madronich, S., Onasch, T. B., Pekour, M. S., Springston, S. R., Thornton, J. A., Tivanski, A. V., and Worsnop, D. R.: Nighttime chemical evolution of aerosol and trace gases in a power plant plume: Implications for secondary organic nitrate and organosulfate aerosol formation, $\mathrm{NO}_{3}$ radical chemistry, and N2O5 heterogeneous hydrolysis, J. Geophys. Res., 115, D12304, doi:10.1029/2009jd013250, 2010.

Zhang, Y., Schauer, J. J., Zhang, Y., Zeng, L., Wei, Y., Liu, Y., and Shao, M.: Characteristics of Particulate Carbon Emissions from Real-World Chinese Coal Combustion, Environ. Sci. Technol., 42, 5068-5073, doi:10.1021/es7022576, 2008.

Zhuang, Y. and Biswas, P.: Submicrometer Particle Formation and Control in a Bench-Scale Pulverized Coal Combustor, Energy Fuels, 15, 510-516, doi:10.1021/ef000080s, 2001. 